\title{
History of EISCAT - Part 1: On the early history of EISCAT with special reference to the Swedish part of it
}

\author{
B. Hultqvist \\ Swedish Institute of Space Physics, Kiruna, Sweden \\ Received: 28 September 2011 - Revised: 23 November 2011 - Accepted: 23 November 2011 \\ - Published: 19 December 2011
}

\begin{abstract}
The paper describes the early history of EISCAT, from the very first ideas and Nordic contacts in the late 1960s to the end of the main development phase, when the facility had become a very advanced and reliable research instrument and its users had developed full competence in the second half of the 1980s. The preparation of the "Green Book", the Beynon meeting in London in 1973 and the activities started there, the first EISCAT Council meeting, the "technical period" 1976-1981, the inauguration in 1981 and the decade of improvements in most of the 1980s are described as seen from the Swedish point of view.
\end{abstract}

\section{The 1960s}

The incoherent scatter radar technique had first been suggested as a method for investigating the ionosphere in USA by Gordon (1958) and had been shown to work experimentally by Bowles, also in USA, in the same year (Bowles, 1958). That was also the year when the research work started at Kiruna Geophysical Observatory, established by the Swedish Academy of Sciences and inaugurated at the beginning of the International Geophysical Year in July 1957. In the following years there was a lot of reporting about this powerful new technique and such facilities were established also in some European countries. As a new researcher in the field of space physics in the auroral region one could not escape envying those who were lucky enough to have access to them. As time passed I realized that there were no incoherent scatter radars in the auroral regions, nor were any plans for such known to me. That, of course, increased the desire to get one in the northern European part of the region, but the cost made it impossible to even think of finding money in Sweden for a Swedish one.

In the middle of the 1960s I had been the official opponent when Olav Holt defended his doctoral thesis at the University of Oslo and we had learnt to know each other. A few years later he became the first professor of physics at the new Uni-

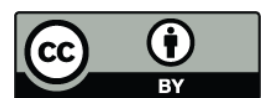

Correspondence to: B. Hultqvist (bengt.hultqvist@irf.se) versity of Troms $\varnothing$, two degrees of latitude north of Kiruna, at the centre of the auroral zone. I phoned him and suggested that we should make an attempt to get an incoherent scatter facility as a joint project of the Nordic countries. We agreed to contact Juhani Oksman in Finland with such a proposal and try to obtain support from URSI at its General Assembly in Ottawa in August 1969. All activities thereafter were based on the assumption by the initial actors that the project would be a Finnish-Norwegian-Swedish joint effort.

During the spring of 1969 we drafted a text of a resolution that we would ask URSI to accept and support. On 2425 June 1969 there was a regional URSI meeting at the MaxPlanck Institute in Lindau, West-Germany. There I reported on our Nordic plans and I also showed the resolution text drafted for URSI, which the meeting supported. I met for the first time Martti Tiuri, professor at the Helsinki University of Technology. He was politically engaged and as such of particular interest to us. He showed great interest in the project and participated actively during the preparations of the EISCAT proposal ("Green Book"; du Castel et al., 1971).

I participated in the URSI General Assembly in Ottawa, Canada, on 18-28 August 1969. Our draft resolution was accepted, which was an important step (the resolution is an appendix to the EISCAT proposal of 1971; see du Castel et al., 1971). But also another incoherent scatter proposal was supported, namely one for a radar on a ship, presented by a French group lead by F. du Castel. So there were two competing European proposals. We returned home rather discouraged. But we would not give up. Juhani Oksman 
agreed to arrange a meeting in Oulu for detailed discussions of a proposal for a Nordic incoherent scatter facility with a transmitter at Kiruna and receivers at, in addition to Kiruna, Troms $\emptyset$ and Sodankylä. The meeting took place on 29 November 1969. I had drafted a proposal text, which was adopted at the meeting and signed by Tiuri, Oksman, Kataja and Koivumaa from Finland, by Holt and Haug from Norway and by me from Sweden. It was for an initial facility, the cost of which was estimated at 20-25 million Skr. (All information from minutes of meetings and related documents in this paper has been taken from archives of the Swedish Institute of Space Physics; only a few references to published papers can be found at the end.)

Already before the Oulu meeting, on 5 November 1969, when I had the first draft of the proposal to be discussed in Oulu ready, I wrote to the Natural Science Research Council (NFR) and the Board for Technical Development of Sweden, with the draft proposal enclosed, asking them to appoint a group representing Sweden in the upcoming discussions of a Nordic incoherent scatter radar and to provide a small amount of money to cover the travel and other costs associated with the meetings. I received half of the amount, the part from the research council. But no group was established. It took eight years before I, as chairman appointed by the NFR, could call the Swedish EISCAT committee to its first meeting in Kiruna on 20 December 1977. In the meantime the research council (NFR) appointed Swedish representatives for each individual meeting. I was involved in most of them together with a representative of NFR, in the beginning mostly Mats-Ola Ottosson and later on also John Gustavsson. For many years I had to apply for travel funds for each meeting, but later on I applied for annual travel grants. At an early stage I was asked by the NFR to accept that we in Kiruna could not apply for additional personnel funds because of the (possible) new facility and I readily agreed that Kiruna Geophysical Observatory (KGO) would supply most general services, including accommodation for EISCAT, in Kiruna.

Before the Oulu meeting I also informed the board of KGO on 21 October 1969 about the incoherent scatter radar plans. The board at that time was the Academy's Board for its Research Stations in the far North, chaired then by the former Minister of Education and Research, Ragnar Edenman, who had taken over the chair after the death in 1966 of the "strongman" behind the coming into existence of KGO in 1957, Professor Rolf Sievert. The board supported the plans, as did all later boards after KGO became a governmental research institute in 1973 (Kiruna Geophysical Institute - KGI and, from 1987, Swedish Institute of Space Physics - IRF) with boards appointed by the Government.

We were not very optimistic about the possibilities of finding the necessary funds for the proposed Nordic facility in our three countries, but we were prepared to try hard. A telephone call, which reached me quite soon after the Oulu meeting, changed the situation. The one calling was du Castel in Paris and he told me that the French were interested in join- ing us in the auroral region project. Suddenly there was a hope of our Nordic project becoming a European one. It was then natural to ask German and British ionosphere research groups about possible interest in joining too.

\section{The preparation of "the Green Book"}

My contacts in Germany in early 1970 were primarily with Harry Kohl at the Max-Planck Institute in Lindau and in England with Nick Taylor at the Royal Radar Establishment at Malvern. Several people participated in the early informal discussions, mainly at various scientific meetings in Europe or by telephone. In some countries the interested scientists had to seek support for participating in the planning work from research councils or similar funding agencies. In England the research council only permitted their scientists to participate as observers, which meant that they could not appear as proposers but only as advisers in the final proposal. In spite of this the British contributions to the work was very big and important partly due to the fact that they had their own experience of incoherent scatter radars.

In the summer of 1970 I called the interested groups in all six countries to a first official planning meeting on 1718 September in Stockholm. There the earlier more preliminary expressions of interest by the European groups became more formal. Unfortunately, I have not been able to find any minutes from that meeting so I am not quite sure that all countries were represented, but those present agreed to prepare a joint proposal for a European facility to be sent to the research councils or corresponding funding agencies in the countries. I believe Tor Hagfors did not participate in the Stockholm meeting but I am certain that he attended the second planning meeting at Nançay as a member of the Norwegian group. He had, with a fresh Ph.D. from the University of Oslo, left Norway for USA, where he became involved in research using advanced radar technique. He became one of the pioneers in the field of incoherent scatter radar research and had been director of more or less all existing facilities of this kind, when we started our planning of a joint European one. Tor became the key figure in the planning work and the first director of the European Incoherent Scatter Facility (EISCAT). (The name EISCAT I proposed in the course of the planning work and it was immediately accepted.)

The Stockholm meeting was followed by a lot of home work and new planning meetings - with home work in between - at Nançay on 14-15 October 1970, Troms $\varnothing$ on 1112 March 1971, Helsinki on 27-28 May 1971 and at Titisee near Freiburg in the middle week of June 1971, where the finalizing of the proposal took place. The "Green Book" was distributed to the various funding agencies a few weeks later. It had 11 reference reports on important questions enclosed with it, which had been worked out in the course of the preparatory work by various members of the planning groups and in a few cases by companies. 
As mentioned earlier, the original Nordic mini-proposal from the Oulu meeting was based on having the transmitter at Kiruna and the three receivers at Troms $\varnothing$, Sodankylä and Kiruna. This was primarily because it would give the best geometry for three-static measurements. This geometry was kept until the late phase of the preparations for the European facility, when Gerhard Haerendel of the Max-Planck Institute of Extraterrestrial Physics in Garching, who had joined the German planning group some time after the start, suggested that the transmitter should instead be placed at Troms $\varnothing$ in order to reach further into the polar cap. This was agreed, as the three-point geometry would still not be unreasonable. In Kiruna we had tried to find suitable transmitter locations with a high horizon to the north to avoid auroral clutter. They were all located at some distance from the Observatory and are shown as receiver locations in the Green Book. With the transmitter in Troms $\varnothing$ we could finally place the Kiruna receiver fairly close to the Observatory within the 22 square kilometre large area of land the Academy rented from the Government.

As the Green Book otherwise gives a fairly complete report of all work that was done by a large number of contributors, I will not deal with it any more but will only note that the estimated capital investment cost for the European facility was two to three times as high as the one of the Nordic version. And it would turn out that it was still an underestimation.

\section{On the "Beynon meeting" in London in 1973 and the planning work it started}

Most of us who had participated in the preparation of the "Proposal for A European Incoherent Scatter Facility in the Auroral Zone (EISCAT)" (see du Castel et al., 1971), dated June 1971, were quite proud of the documents we presented to the funding agencies in the five countries Finland, France, Germany, Norway and Sweden and for information to the Science Research Council of Great Britain. We certainly expected some reaction from them fairly soon, but nothing happened during the first year after submission, nor during the second. No one took any initiative, until finally we received an invitation to a meeting for discussing the proposal from the country whose scientists had not been permitted to participate in it but as observers, Great Britain. It turned out that it was the Executive Director of the Norwegian Research Council (NAVF), A. Sandbo, who had written to the President of URSI at the time, Professor Granville Beynon in Great Britain, suggesting that he, in his capacity within URSI, would call a meeting in London with representatives of all countries involved.

The invitation letter from Professor Beynon was dated 19 September 1973 and the meeting took place on 25 October at the office of Science Research Council in central London. Besides Professor Beynon another most important person participated in that meeting, Dr. F. Schneider, Secretary General of Max-Planck Gesellschaft. He had quite a positive attitude towards the EISCAT plans and helped very much in making the "Beynon meeting" the start of a very intense planning period that ended with the signing of the EISCAT agreement by all six countries, Finland, France, Great Britain, Norway, Sweden and West-Germany, in December 1975. Hans Wilhelmsson, John Gustavsson and I represented NFR at the meeting. I had a sabbatical year in 1973 and received the invitation to the meeting in Boulder, Colorado, where I worked in the space physics group of the National Oceanic and Atmospheric Administration (NOAA). I had almost given up hope that anything would happen with the EISCAT plans.

A Steering Committee was set up in London with Schneider as chairman and Hagfors as secretary. It should contain two members from each country, one scientist and one administrator. The tasks were to review the Green Book and make a comprehensive feasibility study ("The Yellow Book"; see The EISCAT Steering Committee, 1974). It should also review all other aspects of the EISCAT project, managing, operation, financing etc. The Swedish members of it became Hans Wilhelmsson and John Gustavsson. It presented its report, "The Yellow Book", in June 1974, but it dealt only with the UHF radar, as the VHF one would be handled mainly by the British when/if they could join the cooperation.

At the London meeting in October 1973 it was hoped to have an agreement in principle ready by February 1974. It took in fact to the end of 1975 before all countries had committed themselves. Sweden and Finland were last as usual. The Swedish research council (NFR) wrote to the Ministry of Education and Research asking for permission to join EISCAT on 8 October 1974 but the permission was given only on 11 December 1975 and NFR signed the Agreement just before Christmas 1975. During the whole of 1975 we in Sweden were very uncertain about how the politicians would decide. A delegation, consisting of the Chairman of NFR, Martin Fehrm, a member of the Council, Ingvar Lindgren, and an administrative leader in NFR, Bengt Samuelsson, together with the Chairman of the board of KGI, Lars Mårdell, and me, visited the Minister of Education and Research, Mr. Zachrisson, on 25 February 1975 in order to try to convince him of the importance of the project, and I wrote a personal letter to Mr. Zachrisson with the same purpose as late as 31 October 1975 . KGO had at an early stage agreed to contribute to the operational costs of EISCAT by providing general services costing $100000 \mathrm{Skr}$ a year without writing invoices to EISCAT, so we really did all we could in Kiruna. In 1980 that amount (increased to $110000 \mathrm{Skr}$ ) was transferred by the Government from KGI to NFR (and on to EISCAT), after which KGI invoiced EISCAT for its services. That simplified bookkeeping everywhere, which may appear astonishing.

A matter that was unclear from the beginning of the planning activities up to November 1975 was the distribution of 
the Scandinavian parts of capital investments and operating costs between Finland, Norway and Sweden. In the Green Book the divisions were 7:11:11 for capital investments and 6:8:10 for running costs. Later on it became 7:9:9 for the sum of investment and running costs, and still later 1:2:2. But Finland had still problems in raising investment funding so at a meeting between representatives of the Nordic countries in Oslo on 19 November 1975, it was agreed to lower the Finnish investment part and increase its part of the running costs during the six first years of operation, with Norway and Sweden adjusting correspondingly so that after $6 \mathrm{yr}$, and afterwards, the total contributions would be in proportions 1:2:2. However, in December the necessary investment funds were found in Finland so the special arrangement mentioned was never used.

The location of the Headquarters of EISCAT was at an early stage more or less agreed to be Kiruna, without having it officially decided. In considering the legal aspects of EISCAT during the preparations of the Agreement, the "legal personality" and "seat" of the organization were up for decision. On 29 July 1974 in Hamburg the Steering Committee needed to know if there were any differences in the relevant laws between Norway and Sweden, which might offer advantages in having the seat in Norway. I wrote a quick report to NFR asking them to involve very quickly legal experts at the Foreign Office and elsewhere in order to identify all ways of reducing taxis and finding advantageous legal forms of the organization. Norwegian and Swedish representatives met shortly thereafter and discussed the matter. No legal reasons to go to Norway were identified.

The Provisional Council of EISCAT invited at its first meeting in London on 17 July 1975 proposals concerning the organization and administration of the activities of EISCAT. Already on 30 May 1975 I had applied to NFR for a grant of $15000 \mathrm{Skr}$ for hiring a consultant to prepare such a proposal with the motivation that, as most activities should follow Swedish laws and regulations, it was natural that Sweden would propose how the organization should be. Obviously there was no doubt at that time that the "seat" of EISCAT would be at Kiruna. As I knew Swedish Space Corporation well (being a member of the board) and thought that that company had an effective and professional organisation and administration, I had discussed the matter with the administrative director there, Klas Änggård, and proposed to Tor Hagfors to write to them for advice (paid with the grant from NFR). Swedish Space Corporation proposed procedures for the following matters: employment contract, retirement rules, travel regulations, account plan, suitable software, economic reporting and currency problems; certainly an impressive list for a small amount of money. However, I have the impression that the first Business Manager of EISCAT, Griff Hodgson, to a large part used systems that he had experience of from England.

Although most of the other member countries were able to sign earlier than Sweden, they could not because the Sci-

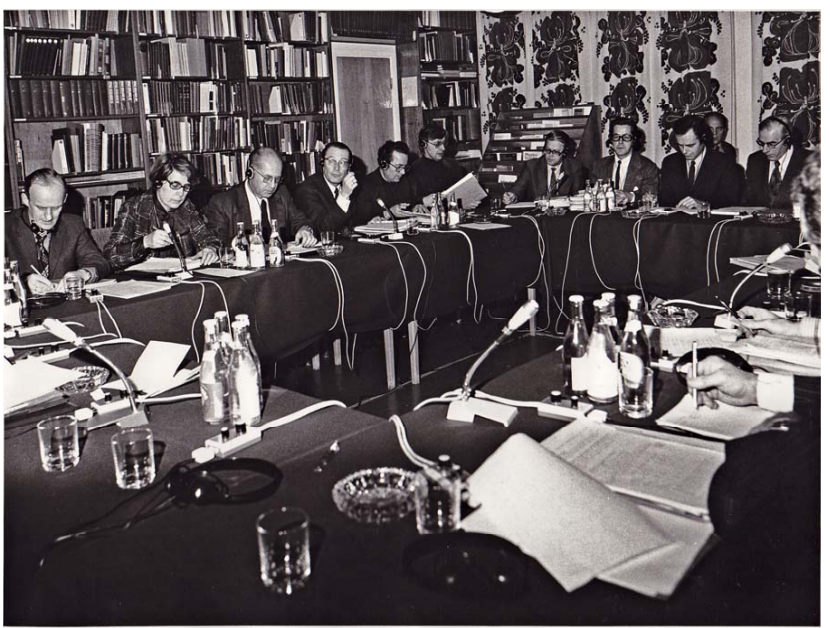

Figure 1. The Council meeting was held in the library of KGI, which was the largest meeting room available but just large enough. The picture was taken from the side of the Chairman near the main entrance door by KGI's photographer. Only about half of the council members can be seen.

ence Research Council of Great Britain finally decided to join EISCAT during the fall of 1975 and that lead to a frantic period of modifications of the Agreement and By-Laws, which ended only after a meeting at Appleton Lab in England on 1-2 December. Had not all member countries been able to sign the Agreement with By-Laws before the end of 1975, the French would have had to put the whole project to new scrutiny in France, according to a statement by the French delegation at the final meeting of the EISCAT Provisional Council in Munich on 6 November 1975. So the luck was with us. At this last Provisional Council meeting it was also decided to hold the first "real" Council meeting, after the birth of EISCAT at Christmas time, in Kiruna on 20 January 1976.

\section{The first EISCAT Council meeting}

The birth of EISCAT and the manifestation of this in the first Council meeting, the leadership of NFR and we in Kiruna thought was an occasion for some celebration. The last days before Christmas NFR sent out some 70 invitations to attend the Opening Cermony at 09:00 MET on 20 January 1976 at Kiruna Geophysical Institute. In addition to the members of EISCAT Council, staff and Scientific Advisory Committee (SAC), each member organisation was invited to bring one additional representative of their country. Five representatives of the Swedish Ministry of Education and Research, including the Minister himself, were invited as was the Chancellor of the Universities, the members of the board of KGI, three leading representatives of the town of Kiruna, the Governor of the County of Norrbotten, and half a dozen leading representatives of major companies and organizations in 
Kiruna. Finally, some representatives of national mass media were invited. The town of Kiruna as usual responded positively to the question if it would offer a dinner for, in the first hand, the foreign guests in the evening.

The Opening Ceremony contained speeches by the Chairman of NFR, Martin Fehrm, the Director of EISCAT, Tor Hagfors, and by P. Creyssel for the Council. It was followed by a press conference. At 10:30 the Council meeting started in the library. The first point on the Council agenda was election of chairmen of the EISCAT bodies and confirmation of the employment of the Directors. Among the Council members it had earlier been more or less agreed that it was most reasonable that representatives of the big European countries would chair Council and its advisory bodies at least during the build-up period, as the Nordic countries were so much involved in development and construction of the various parts of the EISCAT facility. The majority of the contributions of the host countries would be "in kind", i.e. not only buildings and roads would be provided but receivers, computers, timing equipment, $\mathrm{A} / \mathrm{D}$-converters, matched filters etc. would be designed and built by the University of Troms $\varnothing$, Sodankylä Geophysical Observatory, the University of Oulu and KGI, to a fairly large extent with the use of the existing staffs in the four places. Therefore P. Creyssel (F), who had been the chairman of the Provisional Council during the second half of 1975, was proposed to be the first Chairman of EISCAT and that was agreed unanimously. G. Preiss (De) was elected chairman of the Administrative and Financial Committee (AFC) and H. Rishbeth (GB) of the Scientific Advisory Committee, both also unanimously. The employment of the Director, Tor Hagfors, and the two Associate Directors, K. Folkestad and S. Westerlund were confirmed. Another important decision taken at this meeting was to accept the transmitter offer from Aydin in USA at a cost that was much lower than the estimation by Thomson CSF, which had been the basis for the investment budget that was a part of the Agreement. This opened up for a re-planning of the UHF antennas, which finally became fully steerable in all three places.

At 18:00 the council members were transported to the hotel and at 19:30 the town of Kiruna offered a dinner in the city hall for some 50, mainly foreign, guests. Hosts were the Chairman of the City Council, headmaster of the Kiruna schools, Rolf Dahlström, and the Mayor, Folke Granström.

\section{The “technical” period, 1976-1981}

During the early years of EISCAT's existence all efforts were focused on the technical problems associated with designing and constructing the most advanced system of its kind in the world. All meetings, from Council's to SAC's and AFC's, and of the various technical groups were dominated by technical problems. They were many but they were solved one after the other by the Directors and their staffs with the help of several specialised companies. In Kiruna we were building the receivers, with Svante Westerlund as team leader. It was difficult to hold all time schedules, as there were so many problems that were new for the team. Anyhow, the work progressed slowly and there were other problems that took more time to solve in other parts of the system. The most important trouble producers became the transmitters with the gigantic tubes, the klystrons. Some of them were bigger than had been produced before and the solution of all problems associated with them delayed EISCAT with a couple of years. But finally all parts were in such conditions that a date of inauguration could be decided with reasonable hope that it would not be necessary to postpone it again.

\section{The inauguration of EISCAT}

The inauguration was delayed with one year, from August 1980 to tentatively August 1981, at the Council meeting in Lindau on 6-7 November 1979 and at the Council meeting in Paris on 24-25 April 1980 the final date, 26 August 1981, some 16 months later, was agreed. As the inauguration to a large extent would take place in Kiruna, it was natural that I offered a major effort in looking after practical matters involved, in cooperation with the Director and his staff.

A group consisting of one from each Nordic country (Holt, Ranta and I) with the Director, Tor Hagfors, started discussions of a program already before the summer of 1979 , as we at that time hoped to be able to inaugurate in 1980 . The Director wrote to the Royal Court in Stockholm on 25 May 1979 asking for the honour of King Carl XVI Gustaf inaugurating EISCAT in Kiruna in August or early September 1980 . He proposed that a delegation should visit the King at some suitable time to give a more detailed description of EISCAT and of the inauguration plans. Such a delegation, consisting of himself and the President of the Academy of Sciences and Scientific Advisor of the King, Professor Carl Gustaf Bernhard, the Chairman of NFR, Governer Mats Lemne, and me met the King at the Royal Castle on 25 October and it was agreed that the King would inaugurate EISCAT on 27 August 1980. Already at that time the plans were to have the inauguration ceremony simultaneously in Sodankylä, Troms $\varnothing$ and Kiruna, with the speeches given in all three places being possible to be listened to at all three places, and with the participants in Sodankylä and Troms $\varnothing$ being flown to Kiruna after the ceremony to participate in the inauguration banquet in the Kiruna town hall in the evening. Tor Hagfors was not too happy to have to write to the King again on 10 March 1980 with the information that the inauguration was postponed to 26 August 1981, but the King directly accepted to be present on that day.

The financing of the festivities was from the beginning a major problem. NFR and KGI wrote to the Ministry of Education and Research on 6 June 1979 asking for a grant of $30000 \mathrm{Skr}$ and the Minister, J.-E. Wikström, who was to 


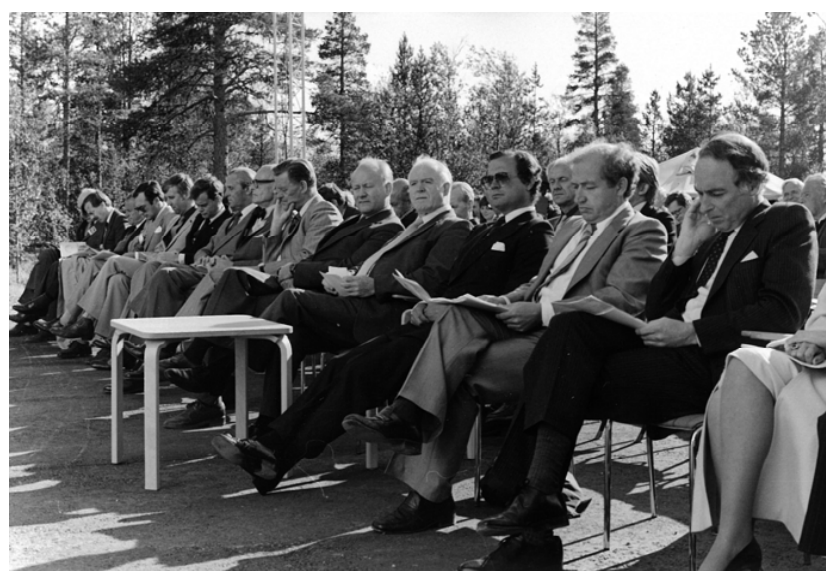

Figure 2. The inauguration ceremony is ready to start outdoors at the Kiruna site. From right in first line: MacFarlane SRC, Minister Wikström, the King, Beynon Council Chair, Hagfors Director, Synnergren Head Royal staff, Bernhard Acad. Sci., Ahrén Court Marshal, Essling Chair Kiruna town council.

be a major figure in the inauguration ceremony more than two years later, provided the amount on 5 July 1979 . In Norway and Finland too additional funds were found. The town of Kiruna again accepted to be host for the inauguration banquet. The chartered airplane, which transported all guests from Stockholm to Kiruna and Troms $\varnothing$ and then from Troms $\emptyset$ to Rovaniemi (Sodankylä) and on to Kiruna and the day after the festivities from Kiruna to Troms $\varnothing$, Rovaniemi, Kiruna and finally to Stockholm, cost a lot. Bids from half a dozen air companies were invited and Scandinavian Airlines System was selected. We charged normal ticket prices between Stockholm and Kiruna and return (except for the King and his company) and with the additional funds from the Nordic countries the costs of the air transport and all local transports by busses were covered. We did not charge anything for the flights from Tromsø and Rovaniemi to Kiruna and back.

The invitations to the inauguration were distributed in the middle of February. They were "signed" by the Chairman of the Council, Sir Granville Beynon (who had been made a baronet since the planning for EISCAT started). Only some 30 of the 330 invitees finally did not attend the inauguration. It clearly indicated a high interest in the member countries.

Kiruna was fairly well equipped with reasonable hotels for the majority of the guests. The King with company and a dozen VIPs were invited to stay in the special hotel of the LKAB mining company, which was by far the best in town and never charged the guests. Of the EISCAT people only Beynon was accommodated there.

In the week before 26 August the weather was poor with rain every day. As the inauguration ceremony had to take place outdoors at the EISCAT site, we realized the risk for rain and had acquired umbrellas with a star map on the inside

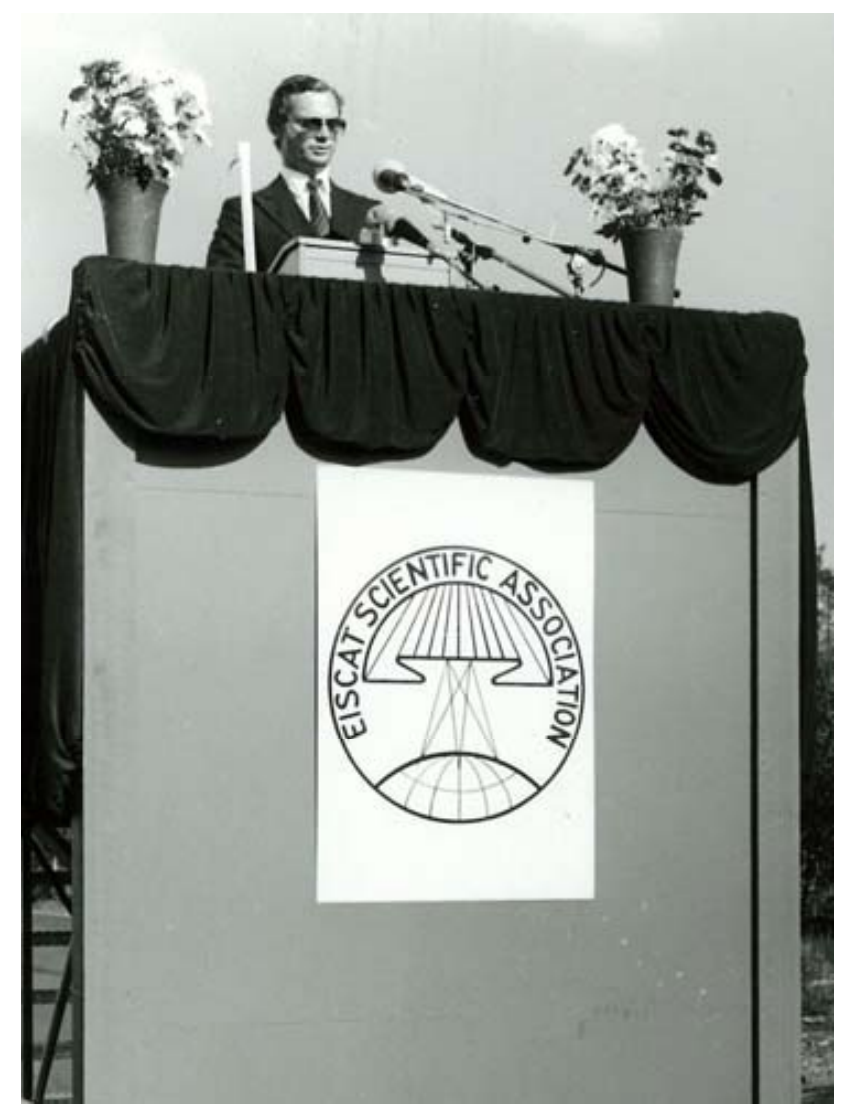

Figure 3. King Carl XVI Gustaf inaugurating EISCAT by pressing a button that gets the $32 \mathrm{~m}$ parabolic antenna move from horizontal position to vertical.

for all participants. We had even selected "umbrella holders" for the King. And so came the 26 August with sunshine and a clear blue sky. No umbrellas were needed and to get rid of the hundreds of them, each participant received one as a souvenir of the inauguration. Everything worked as planned and the antenna moved impressively when the King pressed the red button.

Besides for the inauguration we provided space and time for several meetings, of Council and SAC, as well as boards and committees more or less associated with EISCAT, as the members being present in Kiruna took the opportunity to meet. And in addition transports to see the town, to visit Esrange and the LKAB mine and tours of KGI for the King with company and several other groups were organized. A large part of the staff was busy with the arrangements.

\section{The 1980s, the decade of improvement}

Tor Hagfors announced in the spring of 1981 that he wanted to leave as Director by the end of June 1982. Svante Westerlund worked only half time during 1980 and Phil Williams replaced him as Scientific Director during the spring of 1980. 


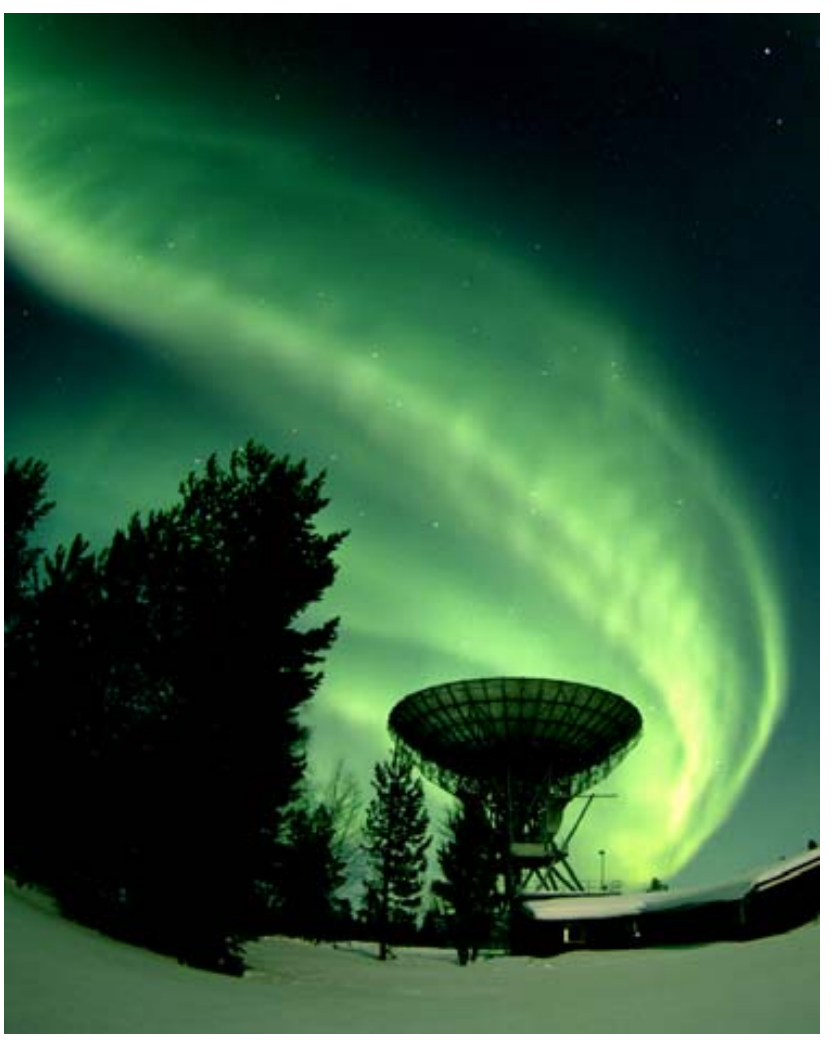

Figure 4. To give an impression of the site, where the inauguration took place, this winter picture has been included.

His contract was for two years and he returned to Aberystwyth in April 1982. So in 1981 we looked for both a new Director and a new Scientific Director. Hagfors had been employed by the university in Trondheim while he filled the position as Director of EISCAT and Williams had been employed by Science Research Council in England. That such solutions had been chosen was because of the high tax levels in Sweden. It would be very expensive for EISCAT to pay them so that after tax they would receive even what they had before.

These problems were accentuated with the successor of Tor Hagfors, Murray Baron from SRI in Menlo Park, California. He was willing to spend some years as Director of EISCAT with the same salary after tax as he had at SRI. To have him employed by SRI while being Director of EISCAT was not an alternative. There was and is a possibility in Sweden to employ an outstanding scientist from outside Scandinavia as guest scientist at a Swedish academic institution for a period of at the most two years with the person paying no tax in Sweden but in his home country. After applying to seven different agencies in Sweden, KGI was permitted to employ Murray Baron for a period of two years as guest scientist and he became Director of EISCAT on 1 September 1982. I tried hard to find some way of prolonging the employment in Sweden with no success.
The new Scientific Director replacing Phil Williams was Juergen Roettger from the Max-Planck Institute in Lindau. He served EISCAT for many years, first as Scientific Director and thereafter, with an intermission of one year spent as Head of the Atmospheric and Ionospheric Division of the Arecibo radar in Puerto Rico, as Director of EISCAT. He was, like Williams, formally employed by his home institution while working for EISCAT. This meant that he could only spend 183 days per year in Sweden without paying Swedish taxes. Even in an international organization with sites in three countries and six member countries, good planning was required in order not to loose efficiency.

Murray Baron used his extensive technical experience of radars to lead the improvement of the technical systems' robustness and reliability. When he left we had a considerably more reliable measuring instrument at our disposal. Only then the process of teaching the interested scientists, among them many young Ph.D. students, in the six member countries about how to use EISCAT became intense. Summer schools were held every year. Scientific results started to come out and they became more and more advanced and interesting as time passed. I remember well several of us more senior EISCAT scientists sitting together during a major scientific conference in Helsinki in 1988 and enjoying our common impression from the sessions that EISCAT and the EISCAT community had reached the top level of the world in the field.

Edited by: R. J. Pellinen

Reviewed by: J. Oksman and three other anonymous referees

\section{References}

du Castel, F., Holt, O., Hultqvist, B., Kohl, H., and Tiuri, M.: A European Incoherent Scatter Facility in the Auroral Zone (EISCAT), published by Auroral Observatory, Troms $\varnothing$, June 1971.

Bowles, K. L.: Observation of vertical incidence scatter from the ionosphere at $41 \mathrm{Mc} / \mathrm{sec}$, Phys. Rev. Lett., 1, 454-455, 1958

Gordon, W. E.: Proc. I.R.E., 46, 1824-1829, 1958.

The EISCAT Steering Committee: A European Incoherent Scatter Facility in the Auroral Zone, Organization and Operation, Implementation of the UHF part of the System, June 1974. 